\title{
Place publiczne miast, jako przestrzeń stymulująca potrzeby czlowieka
}

\author{
Dariusz Gawel, Anna Szafranek \\ Samodzielna Pracownia Architektoniczna, Politechnika Lubelska \\ e-mail:d.gawel@pollub.pl,a.szafranek@pollub.pl
}

Streszczenie: Artykuł jest próbą zdefiniowania warunków realizacji potrzeb społecznych mieszkańców miast w Polsce, w aspekcie tworzenia przestrzeni publicznej. Autorzy w sposób obrazowy próbują określić warunki powstawania i przeobrażania współczesnej przestrzeni publicznej, kreowanej w znacznym stopniu z uwzględnieniem zmieniających się potrzeb ludzkich. Dobór materiału badawczego polskich miast dokonano w oparciu o ich wielkość, czytelną strukturę urbanistyczną śródmieścia oraz zaawansowanie prac w procesie rewitalizacji. Przekształcenia przestrzenne polskich ośrodków miejskich zarówno tych dużych jak i mniejszych ulegają szybkiej intensyfikacji. Powodem tego stanu są niewątpliwie przekształcenia ekonomiczne i ustrojowe kraju, które w znacznym stopniu wpływają na organizację środowiska zurbanizowanego człowieka. Dokonana analiza badanych przestrzeni publicznych w Polsce odbywa się na podstawie współczesnych trendów miastotwórczych, które przeobrażają istniejące środowiska zbudowane, jak na przykład proces rewitalizacji miast.

Słowa kluczowe: przestrzeń publiczna, plac miejski, organizacja i funkcjonowanie miast, potrzeby społeczne człowieka.

\section{Wstęp}

Tworzenie współczesnego środowiska zamieszkania człowieka determinuje kreowanie przestrzeni miejskich w kontekście jego współczesnych potrzeb. Przemiany ekonomiczno-społeczne uwarunkowują jego sposób funkcjonowania w codziennej rzeczywistości. Szczególnie jest to widoczne w dużych miastach. Rytm codzienności (dojazdów i powrotów z pracy, zakupów) wyznacza funkcjonowanie mieszkańca miasta. Konsekwencją tego jest ograniczenie do minimum czasu przebywania w domu. W tej sytuacji człowiek poszukuje adekwatnych form wypoczynku i możliwości zaspokojenia istotnych potrzeb poza swoim własnym mieszkaniem.

Projektanci wychodząc naprzeciw zmianom, które pojawiają się w życiu współczesnych społeczeństw, dążą do kreowania przestrzeni różnorodnych i wielofunkcyjnych umożliwiających zaspokajanie ich potrzeb. Powstaje pytanie na ile i w jaki sposób nowe środowisko miejskie umożliwia zaspokajanie potrzeb społecznych człowieka. Obok potrzeb fizycznych, potrzeba przynależności, łączenia się i szacunku traktowane są jako podstawowe w hierarchii potrzeb ludzkich. W przestrzeni miejskiej terenem (poza miejscem zamieszkania) umożliwiającym realizację podstawowych potrzeb społecznych są place publiczne stanowiące istotną przestrzeń do integracji (rekreacji, spotkań, budowania więzi, wspólnoty) mieszkańców miasta. Z punktu widzenia realizacji potrzeb społecznych mieszkańców miasta, przestrzenie placów publicznych nabierają cech centrum życia społeczno-kulturowego. 
Realizacje przestrzeni publicznych w procesach rewitalizacyjnych wpisują się we współczesne trendy miastotwórcze.

\section{Przestrzeń publiczna w przestrzeni miejskiej}

W kształtowaniu przestrzeni miasta najczęściej dochodzi do odbicia struktury społecznej jego mieszkańców. Specyfika miasta, jego struktura przestrzenna są wynikiem wielu uwarunkowań geograficznych, technicznych i społecznych i ich wzajemnych powiązań.

Budowanie hierarchii przestrzeni nie odbywa się w kategoriach organizacji środowiska miejskiego. W obrębie ośrodka dochodzi często do nakładania się różnych form przestrzeni począwszy od prywatnej, grupowej a skończywszy na przestrzeni publicznej, posiadającej cechy reprezentacyjne. Na wiele tworzonych przestrzeni mamy bezpośredni wpływ jako jej podmioty organizacyjne. Tak dzieje się najczęściej w odniesieniu do przestrzeni prywatnej częściowo grupowej (społecznej). Jednak w przypadku kreowania przestrzeni publicznej częściej decyduje zarządca (władze miasta) nadając jej odpowiedni charakter miejsca o określonych walorach.

O wyjątkowym charakterze przestrzeni publicznej mówi ustawa o planowaniu przestrzennym określając ją jako - „obszar o szczególnym znaczeniu dla zaspokojenia potrzeb mieszkańców, poprawy jakości ich życia i sprzyjający nawiązywaniu kontaktów społecznych ze względu na jego położenie oraz cechy funkcjonalno-przestrzenne, określony w studium uwarunkowań i kierunków zagospodarowania przestrzennego gminy". [1] Definicja ta podkreśla istotne czynniki funkcjonowania takich obszarów w mieście, jak pewnego rodzaju hierarchizacja i alokacja, ale również :

- zaspokojenie potrzeb człowieka,

- powiązanie z zapisami istotnego dokumentu jakim jest studium zagospodarowania gminy.

Inna definicja, stworzona przez P. Lorentza, mówi iż ten fragment przestrzeni miejskiej, który - przez sposób swojego urządzenia oraz lokalizację w strukturze urbanistycznej - jest przeznaczony na potrzeby realizacji bezpośrednich kontaktów pomiędzy uczestnikami życia społecznego oraz inne potrzeby społeczne korzystających z niego zbiorowości, pozostając jednocześnie fizycznie dostępny dla wszystkich zainteresowanych osób. Fizyczna dostępność przestrzeni może być ograniczana czasowo ze względu na kwestie bezpieczeństwa lub sposób organizacji jej wykorzystania”. [2] Specyfika tej definicji podkreśla dość istotne czynniki :

- urządzenie i lokalizację w strukturze urbanistycznej miasta,

- dostępność takich miejsc dla zainteresowanych (możliwości ich wydzielania i ograniczania).

- przeznaczenie na realizację kontaktów międzyludzkich (we wszystkich możliwych formach)

Z kolei K. Wejchert podkreśla przede wszystkim:

- otwartość tych terenów - jako gwarne miejsca spotkań wielu mieszkańców,

- powiązanie ich z obiektami architektonicznymi o różnorodnym znaczeniu - mamy tu dość istotne połączenie specyfiki urbanistycznej miasta, z jego charakterystycznymi budynkami.

Przestrzeń dostępna dla całej społeczności i przybyszy z zewnątrz, gdzie toczy się intensywne życie miasta. Przy niej znajdują się najważniejsze obiekty o znaczeniu społecznym, kulturalnym, obiekty-symbole. [3] 
M. Dymnicka określa w swojej definicji kolejne, jakże szczegółowe zachowania ludzkie - ekspresyjne - a więc i żywiołowe, może nawet entuzjastyczne

„Przestrzeń, do której powinni mieć zagwarantowane prawo dostępu wszyscy obywatele. Jego istotą jest swoboda wyrażania poglądów, ekspresja różnorodnych zachowani (ograniczonych jedynie ogólnymi zasadami współżycia społecznego), bezpośredniość kontaktów". [4]

Wszystkie te definicje unaoczniają ewolucyjne podejście do kreowania przestrzeni publicznej miasta. Nie ograniczają się tylko do samej przestrzeni czy specyfiki miejsca (jego genius loci) a świadomie zauważają w niej użytkownika. Współczesny człowiek wraz ze swoimi potrzebami i możliwościami ich zaspokajania, poprzez mobilność czy statykę staje się istotnym elementem miejsca. Postrzeganie jego indywidualizmu, zmiany w reagowaniu na określone sytuacje w obrębie miejsca, (a jednocześnie tworzenie relacji wraz z innymi obiektami wnętrza urbanistycznego pewnego porządku i ładu) powoduje iż kształt przestrzeni publicznej ciągle się zmienia - ewoluuje.

\section{Zaspokajanie potrzeb ludzkich w zmieniającym się środowisku miejskim}

Potrzeby człowieka są cechą naturalną wpisaną w strukturę osobowości. Realizacja potrzeb, uświadamiania ich i dokonywania własnych odkryć w tym obszarze zachodzi w środowisku w jakim żyje człowiek. Środowisko wielkomiejskie zmienia się i w tej zmieniającej się rzeczywistości funkcjonuje człowiek z całą swoją złożonością (psychofizyczną ), również w zakresie możliwości realizacji swoich potrzeb. Badacze zainteresowani fenomenem potrzeb człowieka opisując je, stworzyli różnorodne klasyfikacje potrzeb (np. Malinowskiego $^{1}$ [5], Szackiego [6], Maslowa ${ }^{2}$ [7], Sujak ${ }^{3}$ [8]. Pomimo, różnic w sposobie klasyfikacji potrzeb, można wyróżnić te, których zaspokojenie ma miejsce tylko w przestrzeni publicznej. Cała gama potrzeb społecznych, związana z obecnością innych ludzi realizuje się właśnie w przestrzeni dostępnej dla innych mieszkańców miasta. Place publiczne nabierają cech unikatowego miejsca w kontekście realizacji potrzeb społecznych człowieka. Same w sobie, place publiczne są wyodrębnionym miejscem w przestrzeni publicznej, które wyróżniają się z otoczenia miejskiego ze względu na swoje cechy. Ich budowa, układ elementów architektonicznych sprzyja lub nie sprzyja gromadzeniu się ludzi w jej przestrzeni. Człowiek jest głównym bohaterem tej wykreowanej przestrzeni, której użytkowanie zależy również od możliwości zaspokojenia jego potrzeb społecznych. To człowiek nadaje sens istnieniu i znaczeniu placów publicznych w przestrzeni miejskiej.

\footnotetext{
Bronisław Malinowski - antropolog i socjolog jest autorem teorii potrzeb i wyodrębnił trzy rodzaje: podstawowe czyli biologiczne (szczegółowo wymienia 7), instrumentalne - które służą do zaspokojenia potrzeb biologicznych (wymienia 4 potrzeby instrumentalne), oraz interaktywne zwane też pochodnymi, te potrzeby są związane z kulturą (nauką, magią, mitem, religią i sztuką).

2 Abraham Maslow - psycholog, znany jako autor teorii hierarchicznej potrzeb. Graficznie teoria ta jest przedstawiana $\mathrm{w}$ formie piramidy, której podstawa stanowią potrzeby podstawowe czyli biologiczne (pożywienia, wody, ciepła) i nad nimi są sytuowane pozostałe: bezpieczeństwa, nad nią potrzeba przywiązania, wyżej uznania i na szczycie znajduje się potrzeba samorealizacji. Nazwa hierarchiczność podkreśla, zdaniem autora, konieczność kolejności ich zaspokojenia. Gdy potrzeby położone niżej w hierarchii są zaspokojone, wtedy ważne stają się te wyżej usytuowane.

3 Elżbieta Sujak - psychiatra i neurolog, pogrupowała potrzeby w trzy grupy, od podstawowych poprzez wyższe do najwyższych . Grupa potrzeb podstawowych obejmuje potrzeby samozachowawcze, gatunkowe oraz potrzeby wartości ,ja”,. Potrzeby wyższe stanowią grupę potrzeb rozwoju oraz potrzeba twórczości. Najwyższe - to potrzeba sensu życia i potrzeby religijne.
} 
Poniżej przedstawiono charakterystykę potrzeb, ich formy uzewnętrzniania oraz możliwości ich realizacji w przestrzeniach placów publicznych, przestrzeniach zaprojektowanych przez człowieka. Pierwsze w kolejności omówione będą potrzeby podstawowe z kategorii społecznych, następnie wyższe - rozwoju i twórczości oraz jako ostatnie w kolejności potrzeby fizyczne, które w hierarchicznych klasyfikacjach traktowane są jako podstawowe.

\subsection{Potrzeby spoleczne - bycia $z$ innymi}

Potrzeba bycia wartością - szacunku, wymieniana jest jako jedna z podstawowych w hierarchii wszystkich potrzeb człowieka [8]. Na uwagę zasługuje fakt, że jest wymieniana obok potrzeb biologicznych (samozachowawczych i gatunkowych). Wskazuje to na wage tej potrzeby i znaczenie jej w rozwoju indywidualnym człowieka. Plac publiczny, jest miejscem wykreowanym do spotkań innych ludzi. Wydarzenia kulturalne, regionalne prezentacje artystyczne lub jakiekolwiek inne sprzyjają gromadzeniu się ludzi czy też schodzeniu się ludzi w dane miejsce. W tych okolicznościach, kiedy się bywa, jest się dostrzeganym przez innych ludzi, można spotkać wyrazy uznania i szacunku ze strony innych. Obecność innych, nieformalne rozmowy umożliwiają zaspokajanie potrzeby kontaktu bezpośredniego. Plac publiczny wyzwala i daje możliwość pozabiznesowej formy komunikacji wśród użytkowników wspólnie dzielonej przestrzeni. Jednym z przejawów uzewnętrzniania się potrzeby bycia wartością jest satysfakcja czerpana z bycia osobą sławną. Pojawienie się osób znanych wzbudza zainteresowania zgromadzonych ludzi, i w sposób pośredni daje poczucie uczestniczenia w znaczącym ,spektaklu”. Efektem tego jest wzrost i poprawa poczucia własnej wartości uczestników tego wydarzenia naznaczonego obecnością „sławy”. Poprzez fakt wspólnego bycia „tu i teraz” pojawia się też poczucie współuczestniczenia i akceptacji. Narasta poczucie budowania wspólnoty, kształtowania się jedności, budowania poczucia „my”.

Plac jako forma architektoniczna wraz elementami budującymi jej przestrzeń stymuluje i rozwija potrzeby społeczne $-\mathrm{z}$ jednej strony, i równocześnie plac publiczny - jako obiekt materialny nabiera charakteru miejsca specjalnego, związanego z pamięcią - historią wydarzeń i wspólnego uczestnictwa. Frey (za: [9] w kontekście przestrzeni architektonicznej i egzystencjalnej, podkreśla fakt doświadczania konkretnej przestrzeni architektonicznej ${ }^{4}$. Przestrzeń placu publicznego, podobnie jak całej architektury, jest odczuwana na poziomie emocji [10]. W ten sposób, poprzez nasycenie przestrzeni przeżyciami użytkowników buduje się tożsamość miejsca w obszarze miasta. Plac publiczny zaczyna nabierać cech miejsca jedynego.

\subsection{Potrzeba rozwoju i twórczości}

Potrzeba rozwoju i twórczości - jest kolejną, której realizacja odbywa się w przestrzeni placu publicznego. Ta potrzeba zajmuje szczególne miejsce wśród innych, wymienianych $\mathrm{w}$ różnych klasyfikacjach. Wyjątkowość polega na jej znaczeniu w rozwoju cywilizacji i kultury świata ludzkiego. Zwierzę powiela zachowania instynktowne, natomiast człowiek, w odróżnieniu od zwierząt tworzy. Kolejne pokolenia wkraczają w zastana cywilizacje i kulturę będącą wynikiem pracy i rozwiązań poprzedniego pokolenia. Pojęcie twórczości rozumiane jest szeroko [11]. Poszukiwanie nieznanych rozwiązań, nietypowe zastosowania przedmiotów, programów, wyjście poza schemat czy przyzwyczajenie. Twórcze podejście wnosi poszukanie rozwiązania zawierającego element nowy, wzbogaconego o „coś” dotychczas nieznanego.

4 „przestrzeń architektoniczna (...) ma strukturę, której należy doświadczać, ponieważ wyraża ona podstawowe cechy ludzkiego bytu" (s. 14-15). 
Potencjał tworzenia wpisany w naturę człowieka realizowany jest w środowisku otaczającym człowieka [12]. Środowisko bogate w bodźce może pełnić rolę wyzwalającą, stymulującą, i wzmacniającą tworzenie. W koncepcji placu publicznego różnorodne obiekty i miejsca ciekawe wzrokowo wyzwalają potrzeby twórczości. W odbiorze działają prowokująco, jak dzieło artystyczne trudne do natychmiastowej klasyfikacji i opisu. Przyciągają uwagę, wymuszają na użytkownikach przestrzeni zatrzymanie i refleksje. Inspirują. Skłaniają do rozmowy i chęci dzielenia się uwagami. Rozwijają.

Warto zwrócić uwagę, że nawet miejsce - teren placu publicznego, bez ściśle zdefiniowanej funkcji (np. utwardzony czy wybetonowany, niewielki obszar na placu publicznym w otoczeniu innych obiektów: ławek) staje się obszarem z potencjałem, z możliwością wypełnienia go wydarzeniami. Pusty obszar staje się przestrzenią do zapełnienia, hyde-parkiem dla wydarzeń. Potrzeba rozwoju i twórczości realizuje się dwustronnie: zarówno dla ludzi występujących i tworzących wydarzenie w przestrzeni placu publicznego, jak również dla obserwatorów - odbiorców, prowokując skojarzenia i inspirując do własnych pomysłów.

\subsection{Potrzeby fizyczne}

Różnorodne klasyfikacje przedstawiające potrzeby człowieka w modelu hierarchicznym, zgodnie sytuują fizyczne potrzeby człowieka jako podstawowe [13], [8]. Zaspokojenia głodu, pragnienia, ale też potrzeba wypoczynku, wolności od doznawania przemocy czy niewoli tworzą grupę potrzeb określanych jako potrzeby samozachowawcze człowieka. Nazwa potrzeby samozachowawcze oddaje charakter potrzeb, i wskazuje również na ich nieustającą obecność w całym okresie życia człowieka. W przestrzeń każdego placu publicznego wkomponowane są obiekty, które umożliwiają zaspokojenie potrzeb podstawowych i przyczyniają się do poczucia dobrostanu fizycznego. Puby, tarasy przy restauracjach, lodziarnie, ruchome miejsca sprzedaży kawy, lub bardziej wymyślnych przekąsek wraz z całą otoczką parasoli zacieniających stoliki, kosze z kompozycjami zieleni dekoracyjnej - tworzą różnorodne rodzaje miejsc do czerpania przyjemności z delektowania się z niespiesznym spożywaniem posiłku.

Miejsce jest kreowane w taki sposób aby zapewniało maksimum wygody fizycznej: zacienienie w upalne dni, wygodne krzesła lub ławy zachęcające do zatrzymania się i posiedzenia, z widokiem na inne osoby lub wydarzenia dziejące się w danym czasie wokół nas. Obiektem ciekawym na obszarze wspólnej przestrzeni publicznej są miejsca z dostępnością do wody. Fontanna jest chyba najczęściej i najbardziej popularną formą wykorzystania wody w przestrzeni miasta dostępną dla ogółu mieszkańców. Przebywanie w pobliżu fontanny daje odczucie fizycznego ochłodzenia w upalne dni, orzeźwienia i odsunięcia od siebie stanu zmęczenia. Nie mniej ważnym elementem postrzegania wody w miejscach publicznych jest jej mobilność, ruch oddający doznania spokoju. Odgłosy szumiącej wody wyzwalają odczucia wyciszenia i ukojenia.

Obecność w pobliżu wody - fontanny jest źródłem wielu przyjemnych sensorycznych odczuć, które przekładają się na poczucie odprężenia i odpoczynku zarówno fizycznego jak i psychicznego. Omawiając potrzeby podstawowe, odczuwalne na poziomie fizycznym osoby, nie sposób pominąć zieleni, i mikroklimatu jaki tworzy. Naturalne elementy przyrody takie jak drzewa, krzewy, klomby stają się elementem architektonicznym w rękach projektantów wkomponowywanym w przestrzeń placu publicznego. Mikroklimat fizyczny, którego parametry można zmierzyć: wilgotność, natężenie światła (zacienienie-nasłonecznienie), cechy powietrza, przekładają się na fizyczne samopoczucie i budują część dobrostanu fizycznego człowieka. Oczywiście, wszystkie elementy architektoniczne w przestrzeni placu 
publicznego winny spełniać wymogi bezpieczeństwa fizycznego, nie narażania człowieka na niebezpieczeństwo, czy zagrożenia.

Przedstawienie potrzeb nastąpiło w pewnym porządku. Jednak warto zwrócić uwagę, że potrzeby wzajemnie się przenikają, zachodzą na siebie. Dlatego też w przestrzeni placu publicznego, jeden element architektoniczny może wyzwalać realizacje kilku potrzeb. To zasób wiedzy, wrażliwości intelektualnej czy artystycznej poszczególnych jednostek, wpływa na poziom i moc aktywnego uczestniczenia i odbioru placu jako całości czy jego elementów. Z drugiej strony bogactwo ,wyposażenia” placu stymuluje osoby do odkrywania i realizacji potrzeb. Plac jest nie tylko fizyczną przestrzenią ale jest miejscem do zaistnienia wielu procesów i zjawisk również na poziomie społecznym - grupowym jak i indywidualnym psychicznym.

\section{Przeobrażenia środowiska zbudowanego miast polskich - analiza wybranych przykładów placów}

Forma i wymiar kreowanej przestrzeni miejskiej w odniesieniu do środowiska zbudowanego nabierają gwałtownego rozpędu. Czasami nie zdajemy sobie sprawy z przemian jakie następują w obrębie terenu związanego z kolejną inwestycją. Nowe budynki powstają zarówno w obrębie centrów miast jak i na obrzeżach, bez istotnej gradacji ich skali, wyrazu i przeznaczenia. Z kolei następne realizacje coraz częściej zaczynamy postrzegać nowe obiekty nie tylko w kategoriach estetycznych, ale również w kategoriach ich nowych cech użytkowych, jak przeznaczenie, energooszczędność, ekologia czy ich inteligencja (smart buildings).

Również w samej urbanistyce miast zaczynamy dostrzegać istotne przemiany. Dobrze znane miejsca ulegają przebudowie, restrukturyzacji (najczęściej dzieje się to w odniesieniu do terenów postindustrialnych) rekompozycji czy rewaloryzacji. We współczesnych czasach większość przekształceń miastotwórcze zaczyna być postrzegane jako swoista płaszczyzna porozumienia inwestora (dewelopera) i użytkownika - mieszkańca..Trendem trwale wpisującym się w postrzeganie przeobrażeń i zmian stała się szeroko rozumiana rewitalizacja polskich miast. Jej sukcesów należy poszukiwać w kategoriach powiązań przestrzennych jakże różnych funkcjonalnie czy organizacyjnie rejonów i dzielnic (zespolenie zdefragmentowanych przestrzeni) powodujących ich większą czytelność poprzez nadanie nowej jakości oraz definiowalność istotnych i węzłowych miejsc. [14]

Poszukując materiałów badawczych do zobrazowania wymienionych zjawisk posługiwano się doborem odpowiedniej skali miast i lokalizacją w obrębie centrów - jako tętniących życiem i chętnie odwiedzanych akceptowanych miejsc. Postrzeganie użytkownika miasta do tej pory odbywało się najczęściej na poziomie jego biernej akceptacji, dziś zaczynamy doświadczać przestrzeni centrów miast poprzez projekty odpowiadające na nowe nieznane dotąd potrzeby.

Dawny plac przy fontannach w Radomiu (jako fragment Placu Konstytucji), stanowi odpowiedni przykład rewitalizowanej przestrzeni centrum miasta. Bezpośrednie sąsiedztwo głównej osi miejskiej jaką stanowi ulica Żeromskiego predysponuje to miejsce do nadania mu charakteru reprezentacyjnego. Sprzężenie tego miejsca $\mathrm{z}$ istotnym elementem struktury Radomia, jakim jest otoczenie kościoła garnizonowego p.w. Św. Stanisława Biskupa, powoduje iż tuż obok historycznej struktury powstała przestrzeń nowoczesna o nieznanej dotąd funkcji centrotwórczej. Plac składa się z małego amfiteatru uniesionego ponad płytę placu, pod którym zlokalizowano kawiarnię. 


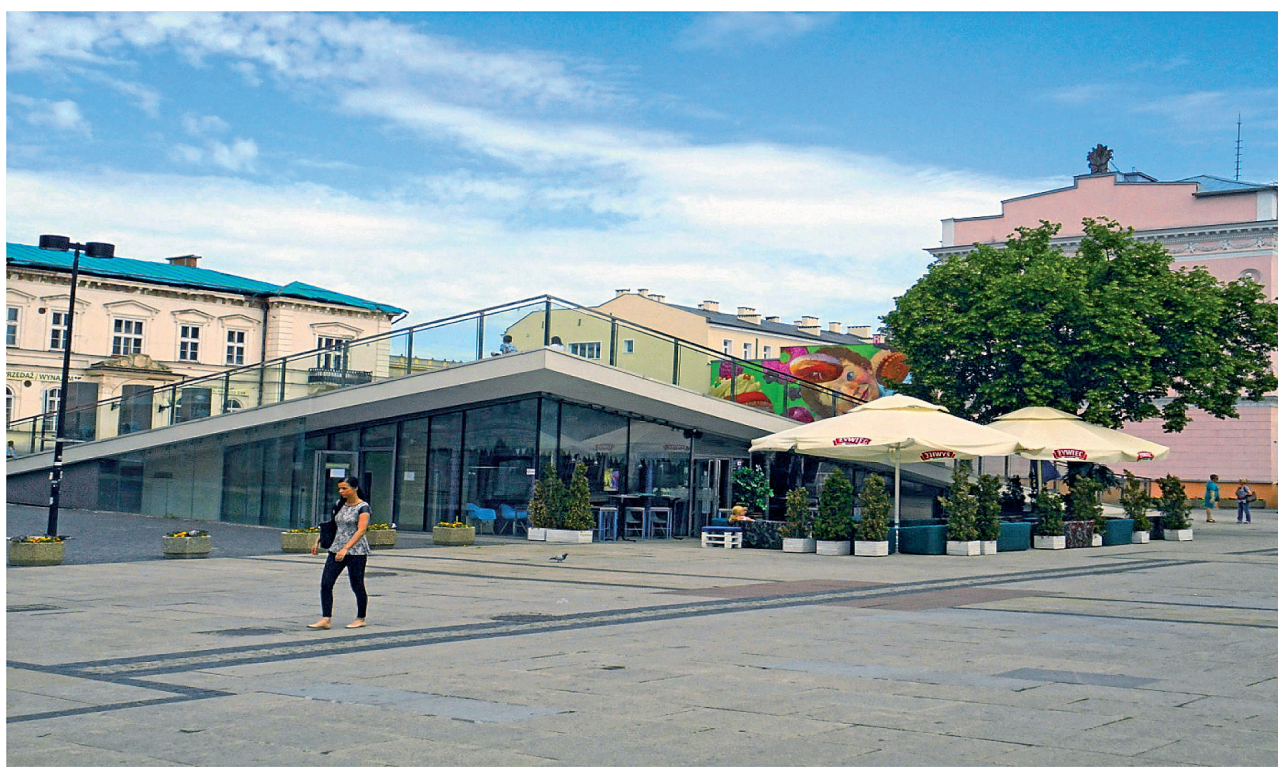

Fot. 1. Wkomponowanie elementu nowoczesnej architektury - amfiteatru, w historyczną przestrzeń centrum Radomia. (Źródło: autor D.G. 2018)

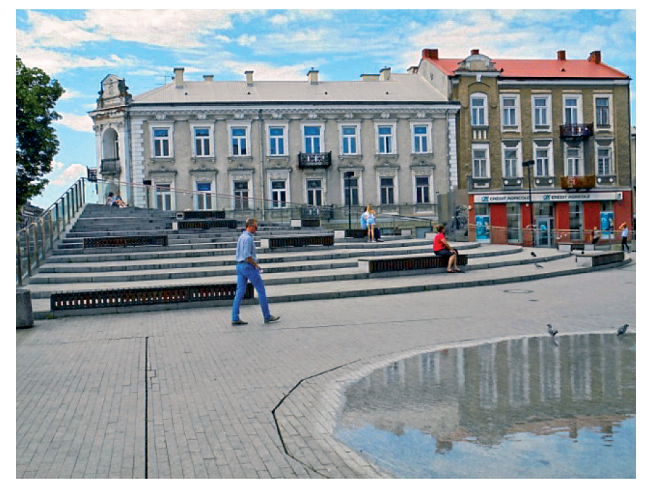

Fot. 2. Skrót pieszy do ul. Focha, z widokiem na amfiteatr. (Źródło: autor DG 2018)

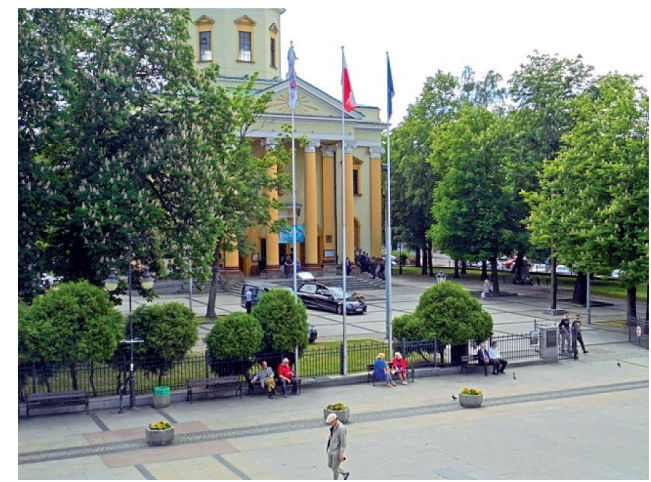

Fot. 3. Plac Konstytucji z Kościołem Św, Bp.Stanisława. (Źródło: autor DG 2018)

Dodatkowo przestrzeń ta jest wzbogacona jest o wbudowane w posadzkę wodotryski i niezależne siedziska. Miejsce to stanowi skrót narożnika do ulicy Focha, dlatego ruch pieszy o obrębie miejsca miesza się z deptakiem miejski. Teren iluminowany kolorowym światłem fontann oraz oświetlony niskimi lampami.

Akceptacja społeczna miejsca przez mieszkańców odbywała się długo. Użytkownikom trudno było przyzwyczaić się do stworzonego miejsca prezentacji sztuki ulicznej czy do gabarytów stworzonej architektury. O ile kolejna kawiarnia zyskała szybką akceptację (z uwagi na przenikanie się mini wnętrza z placem deptaka na zewnątrz), o tyle stworzenie pseudo kondygnacji nad nią wzbudziło zaniepokojenie mieszkańców o kształtowaną przestrzeń publiczną w środowisku historycznym. Ostatecznie plac stał się istotnym elementem struktury miejskiej o funkcji kulturalno-wypoczynkowej. 


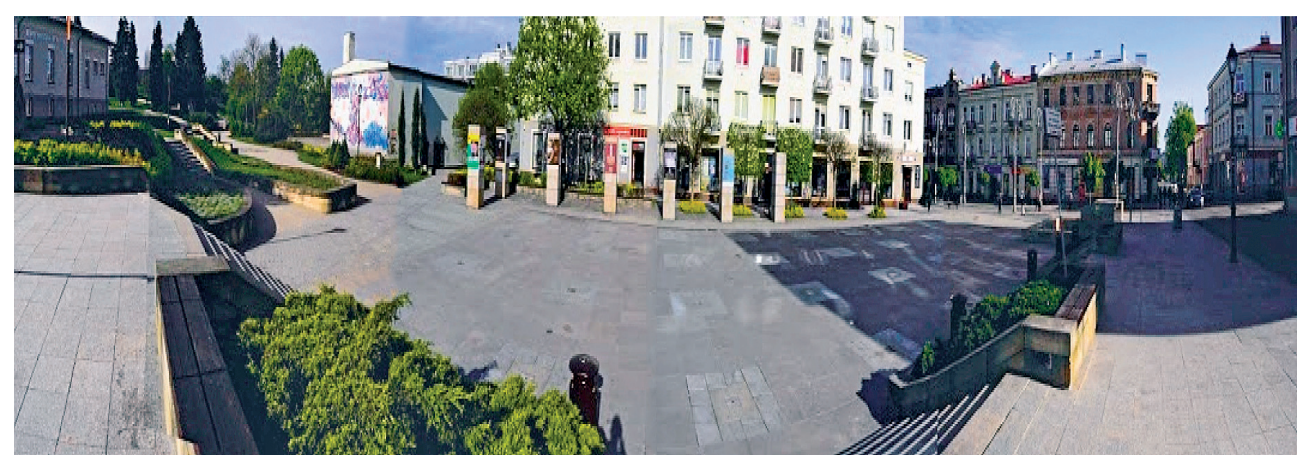

Fot. 4. Panorama Placu Artystów w Kielcach, od otwarcia widokowego na Wzgórze Zamkowe, do zabudowy ul. Sienkiewicza. (Źródło autor DG 2018)

Nieco innym przykładem jest Plac Artystów w Kielcach. Przestrzeń oparta o dwie ważne ulice w tym mieście - Kapitularną - prowadzącą do katedry i Pałacu Biskupiego (ważnych obiektów zabytkowych) i Sienkiewicza, stanowiącą główną oś miejską. [15] Przestrzeń obudowana $\mathrm{z}$ trzech stron $\mathrm{z}$ otwarciem krajobrazowym na zieleń Wzgórza Zamkowego i imponujące wieże obiektów zabytkowych. W zasadzie jest to płaska powierzchnia przeznaczona do prezentacji sztuki, na kiermasze, happeningi i jako miejsce gromadzenia się mieszkańców (spotkania, wiece).

Najważniejszym atutem tej wolnej przestrzeni jest jej otwartość i połączenie z centrum poprzez deptak. Plac stanowi żyjącą przestrzeń odwiedzaną przez zatrzymujących się tu mieszkańców. To tutaj ustawiane są konstrukcje drewniane tężni - w ramach akcji „tężenie sztuki”, lub rzeźby prezentujące różnych autorów. Przez wiele miesięcy plac przekryty był rodzajem sieci pajęczej, tworząc i obrazując nieznane dotąd walory wnętrza urbanistycznego w ramach akcji - krystalizacja przestrzeni. Pomysł na otwartą przestrzeń miejską jest jednocześnie ciekawą formą aktywizacji mieszkańców, wzbogacania życia kulturalnego, uwrażliwieniem na współczesne formy prezentacji sztuki. Lokalizacja w obrębie otoczenia usług centrotwórczych, jak kawiarnie, ośrodka informacji turystycznej czy obiektów handlowych, stwarza możliwość biernego wypoczynku dla użytkowników.

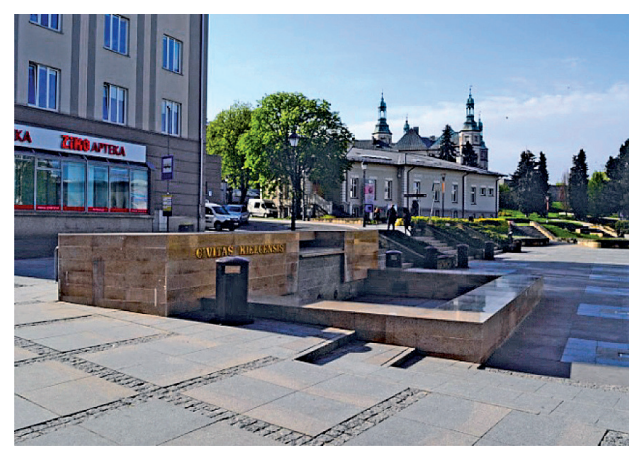

Fot. 5. Detal urbanistyczny - w postaci fontanny. (Źródło: autor D.G. 2018)

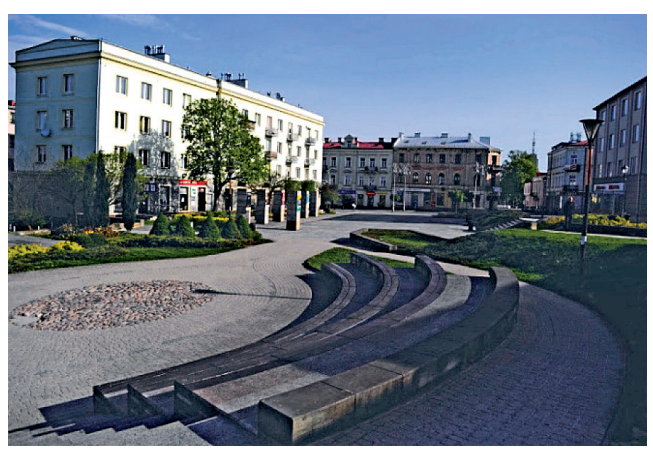

Fot. 6. Niska zieleń miejska, o charakterze wypoczynkowym przy połaczeniu z ul. Sienkiewicza. (Źródło: autor D.G. 2018) 
Kolejnym badanym przykładem jest Plac Litewski w Lublinie. To centralne miejsce w przestrzeni Lublina jest historycznie ukształtowaną strukturą urbanistyczną, obudowaną niską zabudową w większości historyczną. [16]

Jego pierwotne przeznaczenie w momencie tworzenia, czyli w latach 20-tych XIX wieku, to miejsce musztry i parad wojskowych. Jako centralny plac Lublina stał się miejscem obchodów wielu uroczystości i świąt państwowych. Ostatecznie ukształtowana forma uwzględniała centralną fontannę oraz swobodną formę szaty roślinnej w postaci drzew wysokich. Na swojej rozległej powierzchni od ulicy 3 Maja usytuowano pomnik marszałka Józefa Piłsudskiego, obok niego znajduje się też płyta upamiętniająca Nieznanego Żołnierza.

Przez wiele lat plac ten nie był przebudowywany, tracąc w ten sposób swoje walory użytkowe. Ostatecznie władze miasta zdecydowały się na stworzenie projektu rewitalizacji tej zdefiniowanej przestrzeni urbanistycznej. Nowa koncepcja zakładała przywrócenie tego miejsca pieszym mieszkańcom. Docelowo zwycięska koncepcja projektowa zakładała otworzenie $\mathrm{i}$ integrację placu z przedłużonym deptakiem, oraz:

- rekompozycję szaty roślinnej z uwzględnieniem nowych różnorodnych nasadzeń,

- nową posadzkę wraz z zabezpieczeniem reliktów fundamentów historycznego sobo$\mathrm{ru}$,

- stworzenie nowej wieloelementowej multimedialnej fontanny z wodotryskami oraz groblą,

- oświetlenie placu, iluminacje pomników i zabudowy w obrębie całego miejsca.

Stworzone wnętrze urbanistyczne zakłada w centralnym swoim miejscu usytuowanie nowoczesnej formy fontanny składającej się z 2 części. Pierwsza z nich z wieloma małymi płaskimi wodotryskami, druga z pojedynczym centralnie usytuowanym wysokim wodotryskiem. Obydwie części dzieli grobla, która jednocześnie stanowi sprzężenie, obydwu części placu z odnowioną szatą roślinną. Włączenie placu do przestrzeni deptaka odbywa się poprzez stworzenie, płaskiego otwartego przedplacu z wyraźnym rysunkiem posadzki nawiązującym do istniejących jej podziałów.

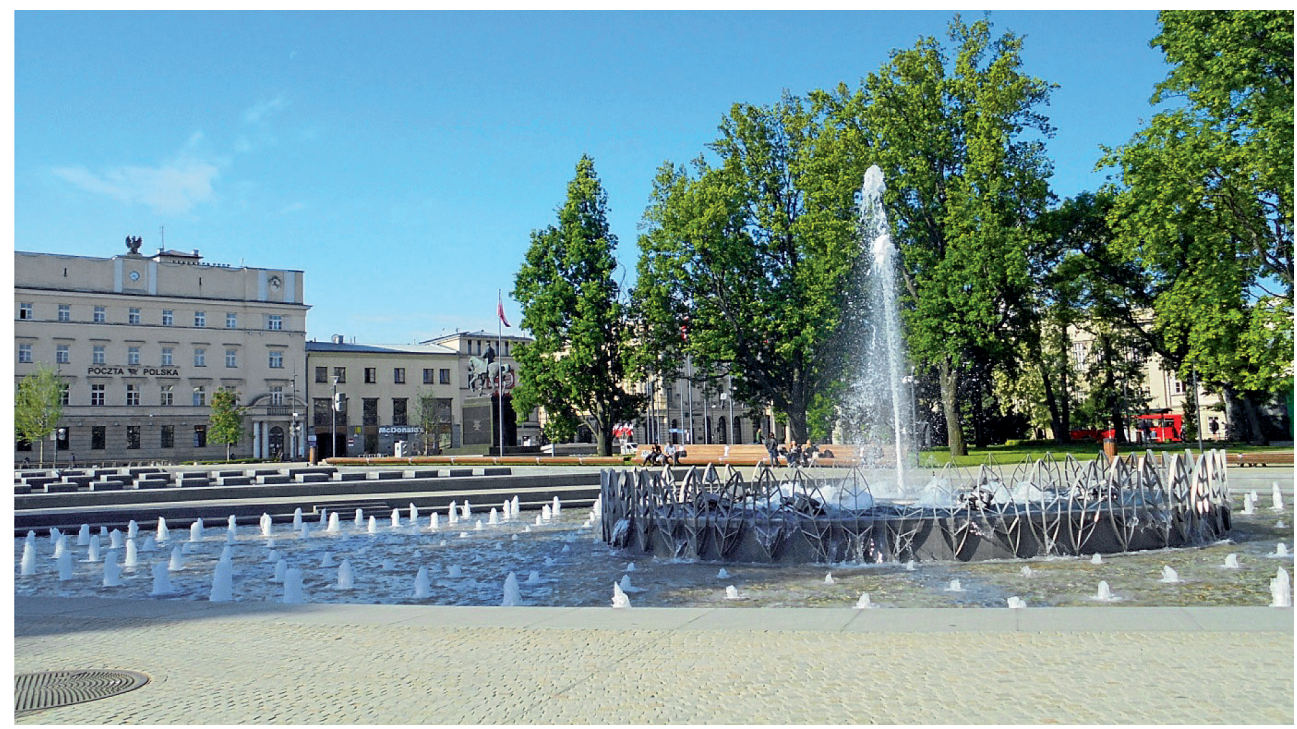

Fot. 7. Główny element Placu Litewskiego w Lublinie, kaskadowa fontanna, w otoczeniu zieleni wysokiej drzew. (Źródło: autor DG 2018) 
W chwili pisania artykułu prace przy realizacji projektu rewitalizacji Placu Litewskiego nadal trwają, można jedynie domniemać iż wpisze się on w całość struktury miejskiej i szybko uzyska akceptację mieszkańców dla których ma służyć.

Opisywane przykłady rewitalizowanych przestrzeni miejskich placów świadczą o tworzeniu nowych interesujących form łączących stare i kreowane struktury miejskie, z uwzględnieniem współczesnych jakże różnorodnych potrzeb mieszkańców. Świadome korzystanie z wielu zróżnicowanych form wyrazu w budowaniu przestrzeni publicznej może służyć scalaniu struktury urbanistycznej miast.

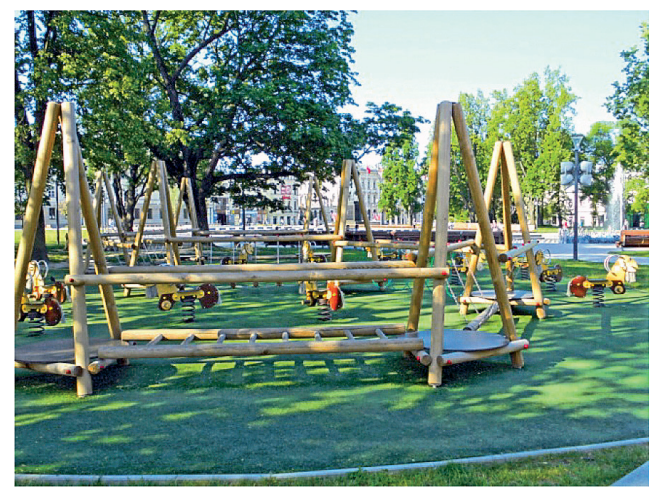

Fot. 8. Koziołkowy plac zabaw w obrębie zieleni P1. Litewskiego. (Źródło: autor DG 2018)

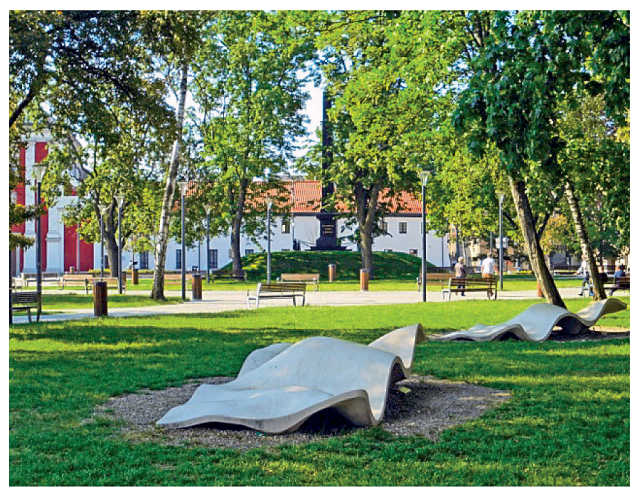

Fot. 9. Detal urbanistyczny jako uzupełnienie zieleni wysokiej. (Źródło: autor DG 2018)

Tabela 1. Badane przestrzenie publiczne - elementy struktury wnętrza urbanistycznego (opracowanie własne)

\begin{tabular}{|c|c|c|c|c|c|c|c|}
\hline Lp. & Miasto & Miejsce & $\begin{array}{l}\text { Funkcja } \\
\text { podstawowa }\end{array}$ & Posadzka & $\begin{array}{l}\text { Obudowa placu } \\
\text { - ściany }\end{array}$ & Sklepienie & $\begin{array}{l}\text { Elementy } \\
\text { wyposażenia }\end{array}$ \\
\hline & 1 & 2 & 3 & 4 & 5 & 6 & 7 \\
\hline 1 & Radom & $\begin{array}{l}\text { Plac } \\
\text { Konstytucji }\end{array}$ & $\begin{array}{l}\text { kulturalno- } \\
\text { wypoczynkowa }\end{array}$ & $\begin{array}{l}\text { płyty } \\
\text { granitowe }\end{array}$ & $\begin{array}{l}\text { hist. zabudowa } \\
\text { kamienicowa }\end{array}$ & brak & $\begin{array}{l}\text { design miejski } \\
\text { detal urbanistyczny }\end{array}$ \\
\hline 2 & Kielce & $\begin{array}{l}\text { Plac } \\
\text { Artystów }\end{array}$ & $\begin{array}{l}\text { ekspozycyjno- } \\
\text { wypoczynkowa }\end{array}$ & $\begin{array}{l}\text { pyty granit } \\
\text { z rysunkiem }\end{array}$ & $\begin{array}{l}\text { zabudowa współ. } \\
\text { z otwarciem } \\
\text { krajobr. }\end{array}$ & okresowe & $\begin{array}{l}\text { rzeźby, } \\
\text { konstrukcje } \\
\text { interaktywne }\end{array}$ \\
\hline 3 & Lublin & $\begin{array}{l}\text { Plac } \\
\text { Litewski }\end{array}$ & $\begin{array}{l}\text { rekreacyjno- } \\
\text { wypoczynkowa }\end{array}$ & $\begin{array}{l}\text { płyty granit } \\
\text { z rysunkiem }\end{array}$ & $\begin{array}{l}\text { hist. zabudowa } \\
\text { kamienicowa }\end{array}$ & $\begin{array}{l}\text { szata } \\
\text { roślin wys. } \\
\text { drzewa }\end{array}$ & $\begin{array}{l}\text { design miejski } \\
\text { detal urbanistyczny }\end{array}$ \\
\hline
\end{tabular}

\footnotetext{
5 „Detal urbanistyczny - jest istotnym elementem kształtowania i organizacji przestrzeni, nadającym jej określone cechy. Detal urbanistyczny powstaje dopiero wówczas, gdy tworzy wraz z innymi elementami wnętrza urbanistycznego całość o sprecyzowanym i zamierzonym charakterze. Nadanie mu określonego charakteru $\mathrm{i}$ indywidualnych cech staje się szczególnie ważne w przypadku rewitalizacji przestrzeni publicznej. Relacje pomiędzy elementami przestrzeni wraz z detalem urbanistycznym powinny tworzyć całość. Okazuje się, iż każdy detal urbanistyczny jest obiektem małej architektury, natomiast nie każdy obiekt małej architektury może być detalem. Różnice w podejściu do definiowania tych obiektów wynikają przede wszystkim ze specyfiki i warunków tworzenia miejsca." [15 s. 87]
} 


\section{Współczesne trendy europejskie w kreowaniu przestrzeni publicznej miast}

Chęć wykreowania w obrębie przestrzeni urbanistycznych miejsc przyjaznych ludziom wymusza poszukiwanie nowych jakże różnorodnych form wyrazu estetycznego. Okazuje się iż współcześni projektanci zaczynają eksperymentować z zastosowaniem adekwatnych form plastycznych, jak światło w postaci wielobarwnych (często laserowych) iluminacji, dźwięk odbijający się we wnętrzu urbanistycznym czy zestawianych form przestrzennych z industrialnych elementów kontenerów transportowych.

Postdamer Platz w Berlinie stanowi przykład jednego z najbardziej ruchliwych miejsc, stolicy Niemiec. Jego historyczne uwarunkowana zabudowa, pełniona funkcja oraz lokalizacja, spowodowały iż stał się istotnym punktem węzłowym miasta, o dużym natężeniu ruchu pieszego i samochodowego (później z lokalizacją stacji metra i kolei miejskiej). Zniszczony w okresie bombardowań w czasie II wojny światowej, został zabudowany murem. Jego wyjątkowość polegała również na łączeniu w sobie linii podziana stref okupacyjnych miasta. Po zjednoczeniu Niemiec i zburzeniu muru berlińskiego stał się istotnym, tętniącym życiem miejscem na mapie miasta. [17] Jego przestrzeń na początku lat 90-tych była sukcesywnie obudowywana nowymi wysokimi obiektami o charakterze mieszkalnym, usługowym i handlowym.

Jednak nie same budynki stały się najistotniejszymi elementami ukształtowanej formy miejsca. Tym elementem stał się dach - rodzaj lekkiego strukturalnego przekrycia placu, rozpięty nad najwyższymi obiektami. W połączeniu z kolorową iluminacją świetlną, dach ten stał się rozpoznawalnym, charakterystycznym elementem tego miejsca.

Poszukiwanie nowych elementów identyfikacji przestrzennej Berlina wpisuje się w trendy kreacji przestrzeni miejskiej (jako nawiązanie do corocznego Festiwalu Świateł, z którego stolica Niemiec słynie). Można stwierdzić iż mieszkańcy zaakceptowali ten charakterystyczny element przestrzeni urbanistycznej, o czym może świadczyć liczba mieszkańców przewijających się przez ten plac.

Innym przekładem jest wykorzystanie wody w obrębie stworzonego nowoczesnego Miasteczka Nauki i Sztuki w hiszpańskiej Walencji (Ciudad de las Artes y las Ciencias). Nowe centrum kulturalno-edukacyjno-rozrywkowe, stanowi kreację futurystycznej architektury nowoczesnych obiektów. [18] Połączenie surowości betonu z lekkością i transparentnością (przeźroczystością i jasnością) szkła dało bardzo ciekawe efekty w postaci ogromnych w skali obiektów użyteczności publicznej (muzea, galerie, oceanaria, centra konferencyjne, sale koncertowe). Lokalizacja tego kompleksu została wyznaczona w obrębie 2 kilometrowego pasa dawnego koryta rzeki. Uzupełnieniem całości jest szata roślinna eksponowana dość oszczędnie, lecz świadomie. Natomiast charakterystyczną formą wyeksponowania tej części miasta była woda. Zabieg świadomy z uwagi na nawiązanie do dawnego śladu przebiegu rzeki Turi.

Kolejny raz odnotowano wykorzystanie takich cech cieczy jak gładkość i odbicia w lustrze wody. Ogromna powierzchnia płaszczyzny wody stanowi przeciwwagę dla stworzonej skali nowoczesnych inteligentnych budynków (smart building). Człowiek znajdujący się w tym miejscu, przy tej skali zabudowy doświadcza asymilacji z wykreowanym środowiskiem zurbanizowanym miejskim. Poprzez swoją odmienność (w porównaniu do reszty miasta) Miasteczko Nauki i Sztuki stało się nie tylko przestrzenia publiczną w skali miasta, ale raczej w skali kraju. 
Następnym charakterystycznym miejscem jest industrialny muzyczny plac zabaw dla dzieci w Manchesterze. Jego na pozór chaotyczną przestrzeń tworzą ściany złożone ze stalowych kontenerów transportowych będących miejscem eksperymentów muzycznych. [19] Kontenery ułożone są w postaci elipsy - co ma pomagać w rozchodzeniu się i odbiciu fal dźwiękowych. W celu zakłócenia linearnego układu krawędzi kontenerowych, wysokość obudowy przechodzi od jednej do trzech poziomów. Wnętrze placu wypełniają swobodnie poustawiane instrumenty muzyczne, gdzie dzieci doświadczają świata dźwięków na organizowanych imprezach i warsztatach.

Ilość różnorodnych wrażeń jest spotęgowana poprzez pomalowanie kontenerów w dość kontrastowych kolorach. Zabawa dźwiękiem przez najmłodszych ma charakter eksperymentów przybliżających nowy nieznany świat muzyki i dźwięków. Cała przestrzeń placu przekryta jest brezentową tkaniną w postaci żagli, zacieniając goi tworząc przyjazny mikroklimat dla dzieci w obrębie centrum miasta. Takie nawiązanie do industrialnego charakteru można również odczytywać jako podkreślanie przemysłowego i portowego charakteru zurbanizowanej przestrzeni miasta Manchester.

Przytoczne przykłady wykorzystania i zaaranżowania przestrzeni publicznej są bardzo różnorodne. Operowanie różnym środkami tworzenia przestrzeni miejskiej pozwala na zaspokajanie coraz bardziej wysublimowanych i różnorodnych potrzeb mieszkańców.

\section{Podsumowanie i wnioski}

W artykule przedstawiono charakterystykę wybranych placów publicznych w aspekcie możliwości zaspokajania potrzeb mieszkańców tych miast. Analiza wybranych przykładowych placów pokazała, że rewitalizacje tych przestrzeni w coraz większym stopniu uwzględniają potrzeby człowieka. Możliwości realizacji potrzeb są wynikiem zmian tempa życia pojedynczych mieszkańców, które podporządkowane/wynikiem/ związane są współczesnym procesom organizacji życia społecznego.

Wniosek, który wyłania się z analizy potrzeb, to wzmocnienie roli mieszkańców w partycypowaniu decyzyjnym odnoszącym się do danej przestrzeni. Konsultacje społeczne jako sposób zaangażowania mieszkańców w tworzenie wspólnej przestrzeni oraz wspólne uzgodnienia, mają za cel poznanie preferencji potrzeb i ich możliwości realizacji. Innowacyjność tworzenia nowych przestrzeni publicznych w obrębie miast wymaga również od samych projektantów wpisania się w kanon potrzeb ludzkich, zmieniających się wraz z wymogami czasów.

Każda społeczność może się różnić w zapotrzebowaniu na określone obiekty, które dla niej są ważne w danym momencie. Zróżnicowania i w związku z tym zapotrzebowanie na przestrzeń o określonych cechach może zależeć między innymi od wieku, płci i kulturowego zasobu społeczności. Place publiczne wymienione powyżej są przykładem poszukiwania różnorodnych rozwiązań architektonicznych i przestrzennych, które próbują wychodzić naprzeciw potrzebom mieszkańców miasta. 
Tabela 2. Realizacja potrzeb człowieka w badanych przestrzeniach publicznych centrów miast - synteza wniosków (opracowanie własne)

\begin{tabular}{|c|c|c|c|}
\hline \multirow{2}{*}{$\begin{array}{c}\text { Potrzeby } \\
\text { indywidualne }\end{array}$} & \multicolumn{3}{|c|}{ Sposoby realizacji w poszczególnych miejscach } \\
\hline & $\begin{array}{c}\text { Radom } \\
\text { Plac Konstytucji }\end{array}$ & $\begin{array}{c}\text { Kielce } \\
\text { Plac Artystów }\end{array}$ & $\begin{array}{c}\text { Lublin } \\
\text { Plac Litewski }\end{array}$ \\
\hline 1 & 2 & 3 & 6 \\
\hline głodu i pragnienia & kawiarnia & obsługa środowiskowa & obsługa środowiskowa \\
\hline wypoczynku & biernego & biernego i aktywnego & biernego i aktywnego \\
\hline wygody fizycznej & $\begin{array}{l}\text { odl. ergonomiczna } \\
\text { elem. wyposażenia }\end{array}$ & $\begin{array}{l}\text { odl. ergonomiczna } \\
\text { elem. wyposażenia }\end{array}$ & $\begin{array}{l}\text { odl. ergonomiczna } \\
\text { elem. wyposażenia }\end{array}$ \\
\hline mikroklimatu & $\begin{array}{l}\text { szata roślinna, zacienienie, } \\
\text { zamgławianie }\end{array}$ & $\begin{array}{l}\text { częściowe (czasowe) } \\
\text { przekrycie }\end{array}$ & $\begin{array}{l}\text { szata roślinna, zacienie- } \\
\text { nie, zamgławianie }\end{array}$ \\
\hline bezpieczeństwa & $\begin{array}{l}\text { oświetlenie i iluminacja } \\
\text { zabudowy, monitoring } \\
\text { miejsca }\end{array}$ & $\begin{array}{l}\text { oświetlenie i iluminacja } \\
\text { zabudowy, monitoring } \\
\text { miejsca }\end{array}$ & $\begin{array}{l}\text { oświetlenie i iluminacja } \\
\text { zabudowy, monitoring } \\
\text { miejsca }\end{array}$ \\
\hline $\begin{array}{l}\text { bycia wartością } \\
\text { i szacunku }\end{array}$ & $\begin{array}{l}\text { estetyka wnętrza } \\
\text { i org. przestrzeni }\end{array}$ & $\begin{array}{l}\text { org. przestrzeni, } \\
\text { widok na otoczenie }\end{array}$ & $\begin{array}{l}\text { estetyka wnętrza } \\
\text { i org. przestrzeni }\end{array}$ \\
\hline $\begin{array}{l}\text { posiadania więzi } \\
\text { międzyludzkich }\end{array}$ & $\begin{array}{l}\text { budowanie } \\
\text { mikroprzestrzeni } \\
\text { elem. wyposażenia }\end{array}$ & $\begin{array}{l}\text { open space } \\
\text { elem. wyposażenia }\end{array}$ & $\begin{array}{l}\text { budowanie } \\
\text { mikroprzestrzeni } \\
\text { elem. wyposażenia }\end{array}$ \\
\hline $\begin{array}{l}\text { kontaktu } \\
\text { bezpośredniego }\end{array}$ & rozrywka i zabawa & imprezy okolicznościowe & imprezy okolicznościowe \\
\hline $\begin{array}{l}\text { poczucia } \\
\text { wspólnoty „my” }\end{array}$ & $\begin{array}{l}\text { miejsce spotkań } \\
\text { punkt węzłowy }\end{array}$ & punkt węzłowy & $\begin{array}{l}\text { miejsce spotkań, } \\
\text { punkt węzłowy }\end{array}$ \\
\hline $\begin{array}{l}\text { rozwoju } \\
\text { i twórczości }\end{array}$ & $\begin{array}{l}\text { amfiteatr - scena, } \\
\text { występy, teatr uliczny }\end{array}$ & $\begin{array}{l}\text { prezentacja sztuki impre- } \\
\text { zy plenerowe, happeningi }\end{array}$ & $\begin{array}{l}\text { imprezy plenerowe, } \\
\text { ruch, teatr uliczny }\end{array}$ \\
\hline
\end{tabular}

\section{Literatura}

[1] Ustawa o planowaniu i zagospodarowaniu przestrzennym - Dz.U. $2003 \mathrm{nr} 80$ poz. 717 z dnia 27 marca 2003 r. z późniejszymi zmianami.

[2] Lorens P., Martyniuk-Pęczek J. (red.), Problemy kształtowania przestrzeni miejskich. Wydawnictwo „Urbanista”, Gdańsk 2010.

[3] Wejchert K. Przestrzeń wokót nas. Fibak Noma Press, Katowice 1993.

[4] Dymnicka M. Przestrzeń dla obywateli. O uniwersalności helleńskiego modelu przestrzeni publicznej, [w:] Człowiek - Miasto - Region. Zwiazki i interakcje, G. Gorzelak, M.S. Szczepański, W. Ślęzak-Tazbir (red.). Wyd. Naukowe Scholar, Warszawa 2009

[5] Malinowski B. Szkice z teorii kultury. Książka i Wiedza, Warszawa 1958.

[6] Szacki J. Historia myśli socjologicznej. PWN, Warszawa 2002.

[7] Zimbardo P., Gerring R. Psychologia i życie. Wydawnictwo Naukowe PWN, Warszawa 2012

[8] Sujak E. ABC psychologii komunikacji, Wydawnictwo WAM, Kraków 2009.

[9] Norberg-Schulz Ch. Bycie, przestrzeń i architektura. Wydawnictwo Murator, Warszawa 2000.

[10] Rasmussen S.E. Odczuwanie architektury. Wydawnictwo Karakter, Kraków 2015.

[11] Nęcka E., Sowa J. Człowiek-umyst-maszyna. Rozmowy o twórczości i inteligencji. Wydawnictwo Znak, Kraków 2005. 
[12] Nęcka E. Społeczny kontekst twórczości, [w:] Psychologia twórczości, Gdańskie Wydawnictwo Psychologiczne, Gdańsk 2012.

[13] Hall C.S., Lidzey G., Campbell J.B. Teorie osobowości. Wydanie nowe., Wydawnictwo Naukowe PWN, Warszawa 2004.

[14] Chmielewski J.M. Teoria urbanistyki w planowaniu miast i osiedli, Oficyna Wydawnicza Politechniki Warszawskiej, Warszawa 2001.

[15] Gaweł D. Detal urbanistyczny rewitalizowanej przestrzeni centrum Kielc, [w:] Kielce - ksztattowanie przestrzeni współczesnego miasta z zachowaniem historycznych obrazów, Monografia - Architektura 5, Wydawnictwo Politechniki Świętokrzyskiej, Kielce 2016

[16] https://pl.wikipedia.org/wiki/Plac_Litewski_w_Lublinie - źródło internetowe, dostępność dnia 22 maja $2017 \mathrm{r}$

[17] https://pl.wikipedia.org/wiki/Plac_Poczdamski - źródło internetowe, dostępność dnia 22 maja $2017 \mathrm{r}$.

[18] http://www.cac.es/es/home.html - źródło internetowe, dostępność dnia 22 maja 2017r.

[19] http://www.bryla.pl/blogi/notwist/2011/08/jeszcze_o_muzyce_w_architekturze_industrialny_ muzyczny_plac_zabaw_w_manchesterze?bo=1 - źródło internetowe, dostępność dnia 22 maja $2017 \mathrm{r}$.

\title{
Public urban places as a space stimulating human needs
}

\author{
Dariusz Gawel, Anna Szafranek \\ Independent Architectural Design Studio, Lublin University of Technology \\ e-mail:d.gawel@pollub.pl,a.szafranek@pollub.pl
}

\begin{abstract}
This article is an attempt to define the conditions under which human social needs can be fulfilled through the creation of urban public spaces in Poland. In a vivid way the authors try to determine how the creation and transformation of urban public spaces can best meet human needs. The spatial transformations of Polish urban centers, both large and small, have intensified and are rapidly developing. The reasons for these changes are undoubtedly due to the economic and political developments currently taking place in Poland, which are having a big influence on the organization of urban environments. The analysis undertaken here of research findings on public places takes into account the current trends in the transformation of the built environment of cities such as urban revitalization.
\end{abstract}

Keywords: public space, square, organization and functioning of cities, human social needs. 